\title{
Distance learning in medical education: an integrative review
}

\author{
O ensino a distância na formação médica: uma revisão integrativa \\ Caio Felipe Thomazin Panicio ${ }^{\circledR 1}$, Angelo Luis Tonon Santana ${ }^{\circledR 1}$, Fernando Torres Bermudes ${ }^{\odot 2}$, \\ Gabriela da Silva Pelegrino ${ }^{\circledR 1}$, Higor Maluta $^{\circledR 1}$, Felipe Lisboa Falkoni de Morais ${ }^{\circledR 1}$, \\ Filipe Ribeiro Boaretto ${ }^{(1}$
}

\begin{abstract}
Introduction: Distance Education (DE) is a teaching modality established with the purpose of expanding the possibilities of access to education, promoting a democratization of access to knowledge. Objective: The objective of the work was to analyze the impact of telemedicine during medical training. Methods: The methodology was an integrative literature review to answer the PICO strategy (P: medical students; I: distance education; C: face-to-face education; $O$ : telemedicine as a harmful factor): Can Telemedicine be harmful to medical training? Results: It was observed that $90 \%$ of the students agreed that this methodology was motivating, and that it favored the active participation of the students. Conclusion: Distance education, when systematized and well applied, allows for greater interaction, improvement of knowledge in a flexible environment, with a consequent improvement in the quality of learning, however it should not aim to replace the traditional medical teaching model, much less when it comes to practical content.
\end{abstract}

Keywords: Education, Distance education, Medicine, Medical students, Telemedicine

\section{Resumo}

Introdução: A Educação a Distância (EaD) é uma modalidade de ensino estabelecida com a finalidade de ampliar as possibilidades do acesso à educação, promovendo uma democratização do acesso ao conhecimento. Objetivo: $O$ objetivo do trabalho foi analisar o impacto da telemedicina

1. Universidade do Oeste Paulista. (UNOESTE). Curso de Graduação em Medicina. Presidente Prudente - SP - Brasil

2. Hospital Regional de Presidente Prudente - HRPP - Presidente Prudente-SP-Brasil

Institution: Universidade do Oeste Paulista - UNOESTE - Presidente Prudente - SP - Brasil

Correspondence address: Caio Felipe Thomazin Panicio. Rua Treze de maio, 279 - Vale das Parreiras - 19033-230 - Presidente Prudente-São Paulo - Brasil. E-mail: caiopanicio@hotmail.com Conflict of interest: There were no conflicts of interest for the present study. durante a formação médica. Método: A metodologia foi uma revisão integrativa da literatura para responder a estratégia PICO (P: estudantes de medicina; I: educação à distância; C: educação presencial; O: a telemedicina como fator prejudicial): A Telemedicina pode ser prejudicial à formação médica? Resultados: Observou-se que $90 \%$ dos alunos concordaram que esta metodologia foi motivadora, e que favoreceu a participação ativa dos alunos. Conclusão: A EaD, quando sistematizada e bem aplicada, permite maior interação, melhoria do conhecimento em um ambiente flexível, com consequente melhoria da qualidade do aprendizado, no entanto não deve ter como objetivo substituir o modelo de ensino médico tradicional, muito menos quando se tratando dos conteúdos práticos.

Palavras chave: Educação, Educação à distância, Estudantes de medicina, Medicina, Telemedicina

\section{Introduction}

Although the term "distance education" has recently become popular, it is nothing new. Correspondence courses were developed by universities around the 19th century and still exist today, in addition to radio being a predominant means of distance learning in the 1930s. Currently, it has become the development of educational television channels. The novelty nowadays is the use of the internet as an instrument for making distance learning feasible ${ }^{(1)}$, which consequently generates a process of migration from a culture of classroom teaching to a virtual culture, in which learning is mediated by information and communication technologies ${ }^{(2)}$. The worldwide computer network, in addition to being a more accessible vehicle, has increasingly provided greater levels of interaction between users.

Distance learning is a challenging educational proposal, involving changes both in the teaching methodology and in the teacher-student relationship ${ }^{(3)}$. It is a teaching modality established with the objective of expanding the possibilities of access to education and knowledge. Its combination with technological and communication advances comes to reduce the difference between the reduced number of places in 
higher education and the demand for social inclusion to a larger portion of the population, promoting a democratization of access to knowledge ${ }^{(4)}$. Distance education democratizes access to education, encourages permanent education and allows professional updating and improvement, requiring less financial resources. The benefits that distance education provides can be explained by its main characteristic, which is the physical separation between teacher and student, allowing the student to decide the best place and time for their study ${ }^{(5)}$. As well as the distance between teacher and student, distance education has its own characteristics that impose the need for new knowledge on the part of those who plan, develop and evaluate the course. The challenge is to apply distance education in a systematic way, in order to improve the quality, effectiveness and efficiency of education ${ }^{(6)}$.

In Brazilian medical education, according to the National Curriculum Guidelines (NCG), the medical graduate will have general, humanistic, critical, reflective and ethical training, with the ability to act at different levels of health care ${ }^{(7)}$. Therefore, it is expected that medical schools are committed to training professionals who have the capacity to respond to the social needs of the population at all levels of health care, including practices in primary care units and internships at university hospitals ${ }^{(8)}$.

In addition to the diversified scenario, the NCGs also propose that undergraduate courses are based on an active methodology, centered on the student and, being the teacher, a facilitator and mediator of this learning process $^{(7)}$. In this regard, distance learning activities have gained progressive space in higher education, with the intention of facilitating the teacher-student relationship. However, with the advent of the pandemic that occurred in the last year to date, Ordinance No. 343, of March 17, 2020, decided on the replacement of face-to-face classes with remote classes for the duration of the COVID-19 pandemic, vetoing the replacement of practical classes and internships in the medical course. On June 16, 2020, the Ministry of Education (MEC) published Ordinance No. 544, authorizing the substitution of internships and practices for remote classes in the medical course.

Following the recommendations of the MEC, medical schools in the country will be able to interrupt this practical contact during the pandemic, which may compromise the process of medical training, since face-to-face contact in stages is essential to consolidate theoretical knowledge.

\section{Objective}

The objective of the work was to analyze the impact of distance learning during medical training.

\section{Methods}

This study presents itself as an integrative literature review of a qualitative and exploratory nature. It is configured as qualitative, as it stimulates the analysis and allows the development of concepts and ideas based on patterns obtained from the studied data and, exploratory because it aims to contribute to a greater understanding of the theme studied.

The integrative review is a methodology used to synthesize the results of studies already carried out, facilitating access and allowing constant updating on the topic of interest ${ }^{(9)}$. It is an important tool that enables the reader to improve himself and institute new practices in his professional routine. Qualitative methods are those in which interpretation by the researcher with his opinions about the phenomenon under study is important ${ }^{(10)}$. While the fundamental objective of an exploratory research is to describe or characterize the nature of the variables that one wants to know ${ }^{(11)}$.

To prepare the review, the methodological process was divided into six stages: identification of the theme and selection of the research question; establishment of inclusion and exclusion criteria; identification of pre-selected and selected studies; categorization of selected studies; analysis and interpretation of results; and presentation of the knowledge review / synthesis.

These aspects facilitated the identification of relevant results and gaps, directing the development of research and assisting professionals in choosing behaviors and making decisions, providing critical knowledge.

\section{Type of study}

An integrative review of the medical literature was prepared using the PICO strategy (Patient, Intervention, Control, "Outcome") to formulate the clinical question of this study, which is: Patient: Medical students; Intervention: Distance education (DE); Control: Classroom teaching; Result: "Outcome": Telemedicine as a harmful factor to medical training.

So, to guide the study, the guiding question was defined: Can Telemedicine be harmful to medical training?

\section{Search criteria}

The bibliographic survey was carried out through electronic search in the databases: Latin American and Caribbean Literature in Health Sciences (LILACS), USA National Library of Medicine (MEDLINE / PubMed), ScienceDirect and in the electronic library 
Scientific Eletronic Library Online (SciELO). The descriptors, selected through the Health Sciences Descriptors (DeCS), were: "students, medical" AND "telemedicine" AND "education" OR "estudantes de medicina" AND "telemedicina" AND "educação".

\section{Eligibility criteria}

First, the articles were searched for in the databases mentioned, and after the initial collection, the articles were filtered and selected. Of the studies, randomized clinical trials, integrative reviews, systematic reviews with meta-analyzes, experimental and cohort study, published between 2011 and 2020 and available in full, were included.

\section{Data extraction}

Data extraction was performed from the complete reading of the studies extracted from the indicated databases. The results obtained from this reading were organized in a spreadsheet containing six dimensions of analysis, in order to enable their categorization. The dimensions of analysis were: year of publication, source of publication, type of study, sample, objectives, main results.

\section{Results}

The searches carried out on the research platforms resulted in 36 articles, 23 of which were excluded for not having a relationship between medical students and Telemedicine. Upon reading the abstracts and, according to the reading of the full text, 17 studies had no direct relationship with the topic. Another 4 are still in progress. At the end of the selection, 2 articles made up the study for meeting the inclusion criteria. To better elucidate the findings, Table 1 shows the distribution of the studies found.

Of the 36 studies found, most were found in the PubMed database, with 24 articles (66.6\%), while in Lilcas only 4 were found.

The distribution of the articles selected for the present study is shown in Table 2, together with their respective title, year and country of publication. While Table 3 presents the studies according to the type of study, sample, objectives and main results.
Table 1

Absolute number $(\mathrm{N})$ and percentage $(\%)$ of all articles found per analyzed database.

\begin{tabular}{ccc} 
Search site & $N$ & $\%$ \\
PubMed & 24 & 66,6 \\
Embase & 8 & 22,2 \\
Lilacs & 4 & 11,1 \\
\hline
\end{tabular}

The studies found correspond to the years 2013 to 2019, representing 2 different countries, Chile and Spain.

According to the types of study presented in Table 3, two randomized clinical trials were found.

\section{Discussion}

Regarding the results obtained, it was observed that $90 \%$ of the students totally agreed that the teaching methodology based on telemedicine was motivating, and that it favored the active participation of the students. On the other hand, only $17.5 \%$ of the students who came into contact with the methodology did not have an active participation. Such differences can be explained by the fact that they are students who are in the transition phase from basic sciences to clinical sciences, which can generate a greater degree of stress when being in physical contact with patients and their families, a situation that does not occur in telemedicine ${ }^{(12)}$.

The results are in line with those obtained by Rienits $^{(15)}$, who observed that third year students at the University of Wollongong in Australia, who participated in a study on telemedicine, positively evaluated this strategy in $88.9 \%$. In the study by Quevedo ${ }^{(12)}$, the assessment of competences: analyzing, synthesizing and presenting an endocrinological medical history, associated with immediate feedback, the student showed a good level of qualification in the three competences assessed. Being congruent with the work of Nilsen, who assessed learning opportunities through the exchange of knowledge between professionals who carry out teleconsultation ${ }^{(12)}$.

Many authors agree that information and communication technologies (ICTs) have enabled greater interaction, improved knowledge in a flexible environ-

\begin{tabular}{|c|c|c|c|}
\hline Authors & Title & Year & Country \\
\hline Quevedo et $\mathrm{al}^{(12)}$ & $\begin{array}{c}\text { Telemedicine as a tool for teaching endocrinology in medical } \\
\text { students }\end{array}$ & 2019 & Chile \\
\hline Segarra et $\mathrm{al}^{(13)}$ & Training effects on the use of computer tools in medical teaching & 2013 & Spain \\
\hline
\end{tabular}


Distribution of included studies according to authors, type of study, and sample, objectives and main results.

Authors Study type/Sample Goals Main results

The performance of students in the teleendocrinology module in assessing the skills

To analyze the scope of competences and the degree of satisfaction of medical students with the use of telemedicine as a didactic strategy in the teaching of endocrinology.

of analyzing, synthesizing and presenting a teleconsulted clinical case was 6.1 on a scale of 1 to 7 , with no differences according to gender. $90 \%$ of students find the teaching methodology based on telemedicine very motivating and $82.5 \%$ consider that this methodology favors the integration of content.

Evaluate the effect of an educational strategy, aimed at teachers and undergraduate and graduate students in the health area, for the application of information and communication technologies

(ICT), as a support in the training process. ment, with a consequent improvement in the quality of learning ${ }^{(14)}$. ICTs are an important means of medical education, having facilitated access to information and modified the teaching and learning process, as well as the management and exchange of information in medicine, an essential element in current medical practice and standards of education ${ }^{(15)}$.

\section{Conclusion}

We have seen, therefore, that distance education, when systematized and well applied, brings numerous benefits to students, allowing more flexibility when studying and accessing unlimited training content, providing a greater range of learning when compared to traditional education students. However, distance education should not aim to replace the traditional medical teaching model, much less when it comes to practical content. Thus, this methodology can be very effective, being used as an additional tool for student learning, and bringing educational advantages when compared only to traditional teaching methods.

\section{References}

1. Heide A, Stilborne L. Guia do professor para a Internet. Porto Alegre RS: Artes Médicas Sul; 2000. 338p.

2. Medeiros MF, Faria ET. Algo de novo sob o sol? Capturas de traçados possíveis na construção do conhecimento produzido em EAD: desafios e intensidades no vivido. In: Silva $\mathrm{M}$, organizadores. Educação Online: Teorias, práticas, legislação, formação corporativa. São Paulo: Edições Loyola; 2003. p.345-67.

3. Medeiros MF, Medeiros GM, Pernigotti JM, Vargas RMF, Colla AL, Herrlein MBP, et al. Virtual learning environments: the challenge of new outlines in the creative production of knowledge. In: Llamas-Nistal M, Fernández-Iglesias MJ, AnidoRifon LE, organizadores. Computers and education. Dordrecht: Springer; 2003. p.51-62.

4. Filatro AC. Design instrucional contextualizado: educação e tecnologia. 2a . ed. São Paulo: SENAC; 2004. 215p.

5. Nunes CS, Pacheco ASV, Nakayama M, Melo PA, Rissi M. Criação e compartilhamento do conhecimento em EAD. Novas Tecnologias em Educação. 2011; 9(1):1-10

6. Bielschowsky CE. O crescimento da educação a distância no Brasil. In: ABRAEAD - Anuário Brasileiro Estatístico de Educação Aberta e a Distância. $4^{\text {a }}$ ed. São Paulo: Instituto Monitor; 2008. 192p.

7. Brasil. Conselho Nacional de Educação. Câmara de Educação Superior. Resolução CNE/CES no 3, de 20 de junho de 2014. Institui Diretrizes curriculares nacionais do Curso de Graduação em Medicina. [Internet]. Brasília(DF); 2014. [2021 Jan 10]. Disponível em: http://portal.mec.gov.br/index. php?option=com_docman\&view $=$ download \&alias $=15874$ rces003-14\&category_slug=junho-2014-pdf\&Itemid=30192

8. Brasil. Ministério da Saúde. Secretaria de Atenção À Saúde. Departamento de Atenção Básica. Política Nacional de Atenção Básica. 4⿳a e ed. Brasília(DF) : Ministério da Saúde; 2007. 68 p. (Série E. Legislação de Saúde) (Série Pactos pela Saúde 2006; v. 4$)$

9. Souza MT, Silva MD, Carvalho R. Revisão integrativa: o que é e como fazer. Einstein. 2010; 8(1):102-6.

10. Pereira AS, Shitsuka DM, Parreira FJ, Shitsuka R. Metodologia da pesquisa científica. In: Pereira AS, Shitsuka DM, Parreira FJ, Shitsuka. Núcleo de tecnologia educacional. Santa Maria: UFMS; 2018. p.63-74. 
11. Köche JC. Fundamentos de metodologia científica: teoria da ciência e iniciação à pesquisa (Edição digital). Petrópolis: Vozes; 2011.

12. Quevedo IL, Matus OB, Arellano JV. Telemedicina como herramienta de enseñanza de la endocrinologia en estudiantes de medicina. Rev Chil Endocrinol Diabetes. 2019; 12(4):199-204.

13. Ortiz Segarra J, Solis Cabrera V, Guachún M, Espinoza A, Mayorga M, Falconí F, et al. Efectos de la capacitación en el uso de herramientas informáticas en la docencia médica. Rev Fac Cienc Méd Univ Cuenca. 2013; 31(2):28-35.

14. Rienits H, Teuss G, Bonney A. Teaching telehealth consultation skills. Clin Teach. 2016; 13(2):119-23.
15. Horna P, Curioso W, Guillén C, Torres C, Kawano J. Conocimientos, habilidades y características del acceso a internet en estudiantes de medicina de uma Universidad Peruana. An Fac Med Univ Mayor de São Marcos. 2002; 63(1):32-9.

Article received: April 04, 2021

Article approved: October 14, 2021

Article published: October 29, 2021

Responsible Editor: Prof. Dr. Eitan Naaman Berezin (Editor-inChief) 